\title{
KEPUTUSAN INVESTASI PADA USAHA MIKRO, KECIL, DAN MENENGAH
}

\author{
Winston Pontoh ${ }^{1}$, Novi Swandari Budiarso ${ }^{2}$ \\ ${ }^{1,2}$ Program Studi Profesi Akuntan, Fakultas Ekonomi dan Bisnis, Univesitas Sam Ratulangi, Jl. Kampus Bahu, \\ Manado, 95115, Indonesia
}

Corresponding e-mail: winstonpontoh@unsrat.ac.id

\begin{abstract}
ABSTRAK
Aktivitas investasi merupakan faktor penting dalam mengembangkan sebuah usaha bisnis yang dijalankan. Aktivitas investasi yang dilakukan pada umumnya dihasilkan dari keputusan investasi yang mempertimbangkan berbagai faktor. Pelaku UMKM secara umum sering tidak memperoleh pengetahuan dan informasi yang cukup dalam menjalankan kegiatan manajerial terkait dengan keputusan investasi. Penerapan ipteks dalam melakukan keputusan investasi menggunakan metode nilai waktu sekarang atau present value method $(N P V)$. Metode ini diharapkan pelaku UMKM dapat memperoleh pemahaman terkait keputusan investasi sehingga dapat mempertahankan keberlanjutan bisnisnya.
\end{abstract}

Kata kunci: UMKM; investasi; ROI; waktu; uang

\section{PENDAHULUAN}

Kegiatan investasi dilakukan oleh para investor guna meningkatkan kesejahteraan yang diharapkan (Mahastanti, 2011; Frensiska et al., 2015). Dalam sudut pandang usaha bisnis, Yuliani (2013) menunjukkan bahwa investasi berperan penting dalam peningkatan nilai perusahaan. Puspitaningtyas (2012) menyatakan bahwa investor perlu memperhatikan dan memahami informasi-informasi yang berasal dari laporan akuntansi sebelum melakukan kegiatan investasi. Lebih lanjut, Puspitaningtyas (2012) menyatakan bahwa pemahaman investor atas informasi-informasi akuntansi perlu dilakukan agar menghindarkan investor dari ketidaktepatan dalam pengambilan keputusan investasi.

Usaha Mikro, Kecil, dan Menengah (UMKM) merupakan jenis usaha yang memiliki potensi usaha yang cukup baik (Bustam, 2016). Lebih lanjut, Bustam (2016) membuktikan bahwa dengan semakin berkembangnya UMKM maka tingkat penyerapan tenaga kerja juga semakin meningkat. Akan tetapi, Suparwo et al. (2018) menunjukkan bahwa UMKM memiliki masalah utama yaitu permodalan yang akan digunakan dalam pengembangan usaha. Berdasarkan hasil penelitian ini, maka dapat diinterpretasikan bahwa salah satu permasalahan utama dari UMKM adalah modal usaha yang akan digunakan untuk kebutuhan investasi. Penerapan ipteks ini berfokus pada konsep keputusan investasi dengan menggunakan metode nilai waktu sekarang yang dapat dimanfaatkan oleh pelaku UMKM dalam memilih investasi yang akan dilakukan.

\section{TINJAUAN PUSTAKA}

\subsection{Tingkat pengembalian investasi}

Blocher et al. (2010:847) menyatakan bahwa tingkat pengembalian investasi atau return on investment (ROI) merupakan alat ukur jangka pendek atas kinerja keuangan yang berasal dari investasi. Menurut Blocher et al. (2010:847), ROI didefinisikan sebagai laba dibagi dengan nilai yang diinvestasikan, dan diukur dengan menggunakan nilai persentasi. Blocher et al. (2010:847) mengemukakan bahwa semakin besar nilai ROI maka kinerja keuangan semakin baik. Selain itu, Blocher et al. (2010:847) mengemukakan bahwa tingkat tertentu dari ROI bergantung dari beberapa faktor, yaitu kondisi umum ekonomi, dan kondisi umum industri perusahaan. 
Hilton dan Platt (2017:557) menyatakan bahwa dengan adanya tingkat pengembalian investasi atau return on investment (ROI) maka para pengelola akan memperhatikan efektifitas pemanfaatan modal untuk kepentingan investasi dan seberapa besar laba yang dihasilkan. Hansen dan Mowen (2007:433) mengemukakan bahwa return on investment (ROI) memiliki 3 (tiga) manfaat, yaitu:

1. ROI mendorong para pengelola usaha untuk memperhatikan keterkaitan antara penjualan, beban-beban perusahaan, dan investasi.

2. ROI mendorong para pengelola usaha untuk mengutamakan efisiensi biaya.

3. ROI mendorong para pengelola usaha untuk mengutamakan efisiensi pengoperasian aset yang dimiliki perusahaan.

\subsection{Konsep nilai waktu uang}

Menurut Ross et al. (2013:88), Horngren et al. (2014:424), dan Block et al. (2017:257), nilai waktu uang terdiri atas 2 (dua) konsep penting, yaitu:

1. Konsep nilai sekarang (present value) adalah nilai sekarang dari uang atas arus kas masuk atau arus kas keluar masa depan. Dalam konsep ini, tingkat bunga tertentu digunakan untuk menghitung nilai tunai, dimana tingkat bunga ini disebut tingkat diskon (discount rates).

2. Konsep nilai masa depan (future value) adalah akumulasi nilai uang (pokok nilai dan bunga) yang akan diterima pada masa yang akan datang.

Kieso et al. (2013:296) menyatakan bahwa, nilai sekarang dari uang (present value) akan selalu memiliki nilai yang lebih kecil dibandingkan dengan nilai masa depan.

\subsection{Metode nilai waktu sekarang dalam keputusan investasi}

Menurut Mulyadi (2001:305), dan Warren et al. (2018), metode nilai waktu sekarang menitikberatkan pada nilai waktu uang. Menurut Mulyadi (2001:305), metode ini mengasumsikan bahwa sebuah usulan investasi dapat diterima apabila nilai tunai pengembalian lebih besar dari nilai investasi yang dikeluarkan atau asset diferensial. Dalam pendapat yang sama, Ross et al. (2013:136) menyatakan bahwa sebuah usulan investasi dapat diterima apabila nilai bersih saat ini (net present value) lebih besar dari nol dan menolak usulan investasi tersebut jika nilai bersih saat ini kurang dari nol.

Mulyadi (2001:305) menyatakan bahwa metode nilai waktu sekarang memiliki kelebihan yaitu memperhitungkan nilai waktu uang, dan seluruh laba bersih selama umur investasi, sedangkan kekurangan dari metode ini adalah perlunya kecermatan dalam memperhitungkan tarif pengembalian investasi. Menurut Ross et al. (2013:138), metode nilai waktu sekarang memiliki prinsip-prinsip yang penting, yaitu: memperhitungkan seluruh arus kas masuk, memperhitungkan arus kas masuk bersih tanpa dipengaruhi periode pencatatan, dan memperhitungkan penurunan nilai uang secara tepat.

\section{METODE DAN TEKNIK PENERAPAN IPTEKS}

Penerapan ipteks dilakukan dengan menggunakan pendekatan studi kasus yang menggambarkan secara lengkap penggunaan informasi akuntansi yaitu laba bersih hingga pada tahap pengambilan keputusan investasi. Teknik penerapan ipteks adalah:

1. Memberikan ilustrasi penentuan proyeksi laba rugi.

2. Memberikan ilustrasi penentuan tingkat pengembalian investasi berdasarkan laba rugi proyeksi dan nilai investasi yang direncanakan.

3. Memberikan ilustrasi dalam menentukan tarif pengembalian investasi dengan menggunakan metode nilai sekarang.

4. Memberikan ilustrasi penentuan nilai tunai laba bersih.

5. Memberikan ilustrasi penentuan keputusan investasi. 
The Studies of Social Science

Volume 2, Issue 1, 2020

pp. 27-32

\section{PEMBAHASAN}

\subsection{Penentuan laba rugi}

Laporan laba rugi merupakan titik awal dalam pemerolehan informasi yang cukup penting yaitu laba bersih. Laba bersih atau sering disebut arus kas bersih dapat diperoleh dengan melakukan identifikasi jumlah penjualan bersih, biaya-biaya terkait, dan beban-beban operasional. Setelah melakukan identifikasi, maka laba atau rugi dapat diperoleh sebagai selisih jumlah penjualan dengan biaya-biaya dan beban-beban. Sebagai contoh kasus, Tabel 1 menggambarkan proyeksi laba rugi per tahun selama 5 tahun.

Tabel 1. Proyeksi laba rugi (disajikan dalam Rp.)

\begin{tabular}{lrrrrr}
\hline \multicolumn{1}{c}{ Keterangan } & Tahun 1 & Tahun 2 & Tahun 3 & Tahun 4 & \multicolumn{1}{c}{ Tahun 5 } \\
\hline Penjualan bersih & 150,000 & 150,000 & 150,000 & 150,000 & 150,000 \\
Biaya-biaya & $(30,000)$ & $(30,000)$ & $(30,000)$ & $(30,000)$ & $(30,000)$ \\
Beban-beban & $(20,000)$ & $(20,000)$ & $(20,000)$ & $(20,000)$ & $(20,000)$ \\
\hline Laba bersih & $\mathbf{1 0 0 , 0 0 0}$ & $\mathbf{1 0 0 , 0 0 0}$ & $\mathbf{1 0 0 , 0 0 0}$ & $\mathbf{1 0 0 , 0 0 0}$ & $\mathbf{1 0 0 , 0 0 0}$ \\
\hline
\end{tabular}

\subsection{Penentuan tingkat pengembalian investasi}

Apabila pelaku usaha telah mengestimasi laba bersih masa datang selama 5 tahun, maka langkah selanjutnya adalah menentukan tingkat pengembalian investasi atau return on investment (ROI). Tingkat pengembalian investasi diperoleh dengan cara:

$$
\frac{\text { Laba setelah pajak }}{\text { Investasi }}
$$

Jika diasumsikan bahwa nilai investasi yang akan dikeluarkan sebesar Rp. 100,000, maka tingkat pengembalian investasi dengan menggunakan metode akuntansi berdasarkan rata-rata laba bersih selama 5 tahun atau Rp. 100,000 (Rp. 500,000/5 tahun) adalah sebesar $100 \%$. Penghitungan tingkat pengembalian investasi dengan menggunakan pendekatan metode akuntansi merupakan metode penghitungan yang didasarkan pada informasi keuangan khususnya yang berasal dari laporan laba rugi yang dihasilkan secara akuntansi (Mulyadi, 2001:301). Penghitungan tingkat pengembalian investasi atau return on investment (ROI) disajikan sebagai berikut.

$\begin{array}{ll}\text { Laba bersih tahun 1 } & \text { Rp. 100,000 } \\ \text { Laba bersih tahun 2 } & \text { Rp. 100,000 } \\ \text { Laba bersih tahun 3 } & \text { Rp. 100,000 } \\ \text { Laba bersih tahun 4 } & \text { Rp. 100,000 } \\ \text { Laba bersih tahun 5 } & \text { Rp. 100,000 } \\ \text { Rata-rata laba bersih } & \text { Rp. 100,000 } \\ \text { Nilai investasi } & =\text { Rp. 100,000 } \\ \text { ROI } & =\frac{\text { Rp. } 100,000}{\text { Rp. } 100,000} \\ & =1 \text { atau } 100 \%\end{array}$




\subsection{Penentuan tarif pengembalian investasi}

Saat pelaku UMKM telah menentukan tingkat pengembalian investasi, maka tahap selanjutnya adalah melakukan penghitungan tarif pengembalian investasi. Jika diasumsikan bahwa pelaku UMKM mengharapkan jangka waktu untuk pengembalian investasi yang dikeluarkan adalah selama 5 tahun, maka penentuan tarif dapat dilakukan dengan menggunakan rumus metode nilai waktu sekarang atau present value method.

$$
\frac{1}{(1+n)^{1}}
$$

Berdasarkan metode nilai waktu sekarang diketahui bahwa $\mathrm{n}$ adalah tingkat pengembalian investasi atau ROI sedangkan i adalah tahun.

Tabel 2. Penghitungan tarif pengembalian

\begin{tabular}{lllr}
\hline & & & Tarif pengembalian \\
\hline Tahun 1 & $1 /(1+1)^{1}$ & $=$ & 0.5 \\
Tahun 2 & $1 /(1+1)^{2}$ & $=$ & 0.25 \\
Tahun 3 & $1 /(1+1)^{3}$ & $=$ & 0.125 \\
Tahun 4 & $1 /(1+1)^{4}$ & $=$ & 0.0625 \\
Tahun 5 & $1 /(1+1)^{5}$ & $=$ & 0.03125 \\
\hline
\end{tabular}

\subsection{Penentuan nilai tunai laba bersih}

Penentuan nilai tunai laba bersih dengan menggunakan metode nilai waktu sekarang bertujuan untuk mengetahui nilai tunai yang akan diperoleh atas hasil pengembalian investasi yang telah diproyeksi pada masa sekarang. Berdasarkan Tabel 2, penghitungan nilai tunai laba bersih berdasarkan waktu diperoleh dengan menggunakan tarif pengembalian yang telah diperoleh sehingga pelaku UMKM dapat memperoleh jumlah keseluruhan atas pengembalian atas investasi yang telah dikeluarkan.

Tabel 3. Penghitungan nilai tunai laba bersih

\begin{tabular}{crrr}
\hline Tahun & $\begin{array}{c}\text { Laba bersih (Rp.) } \\
(\mathbf{1})\end{array}$ & $\begin{array}{c}\text { Tarif pengembalian } \\
(\mathbf{2})\end{array}$ & $\begin{array}{c}\text { Nilai tunai laba bersih (Rp.) } \\
(\mathbf{3})=(\mathbf{1}) \mathbf{x}(\mathbf{2})\end{array}$ \\
\hline 1 & Rp. 100,000 & 0.5 & $50,000.00$ \\
2 & Rp. 100,000 & 0.25 & $25,000.00$ \\
3 & Rp. 100,000 & 0.125 & $12,500.00$ \\
4 & Rp. 100,000 & 0.0625 & $6,250.00$ \\
5 & Rp. 100,000 & 0.03125 & $3,125.00$ \\
\hline & Total & $\mathbf{9 6 , 8 7 5 . 0 0}$ \\
\hline
\end{tabular}

\subsection{Penentuan keputusan investasi}

Pelaku UMKM pada umumnya menandingkan nilai tunai pengembalian yang diperoleh dengan nilai investasi berdasarkan nilai historis. Apabila menggunakan penghitungan berdasarkan nilai historis maka investasi ini akan sangat menguntungkan. Akan tetapi hasil yang diperoleh pada Tabel 3 menunjukkan bahwa jumlah keseluruhan nilai tunai laba bersih adalah sebesar Rp. 96,875, sehingga jika ditandingkan dengan jumlah investasi Rp. 100,000, maka pelaku UMKM dapat menolak investasi ini. Hal ini disebabkan karena nilai keseluruhan yang akan diterima hingga akhir tahun ke-5 kurang dari nilai investasi sehingga menimbulkan kerugian sebesar Rp. 3,125. Akan tetapi jika pelaku UMKM tidak ingin menolak investasi ini, maka alternatif keputusan lainnya adalah pelaku UMKM dapat menambah jangka waktu investasi lebih dari 5 tahun. 


\section{KESIMPULAN DAN SARAN}

Secara umum, UMKM merupakan organisasi bisnis yang masih membutuhkan pemahaman atas strategi pengambilan keputusan khususnya yang terkait dengan investasi. Keputusan investasi merupakan keputusan atas kegiatan melakukan investasi dalam rangka mengembangkan dan mempertahankan keberlanjutan dari usaha bisnis. Keputusan investasi memerlukan pemahaman atas data dan informasi terkait yang merupakan komponen penting dalam melakukan penghitungan nilai investasi, tingkat pengembalian, dan nilai pengembaliannya.

Metode nilai waktu sekarang atau present value method (NPV) merupakan metode yang sering digunakan dalam menghitung tingkat pengembalian dan nilai pengembalian atas investasi yang dikeluarkan. Berdasarkan metode nilai uang waktu sekarang maka para pelaku UMKM dapat memilih keputusan investasi yang tepat bagi pengembangan atau keberlanjutan usaha bisnis. Jenis keputusan yang umumnya diambil berdasarkan metode nilai waktu sekarang adalah menerima atau menolak investasi yang dibutuhkan. Secara praktis, alternatif keputusan investasi yang lain adalah memperpanjang periode pengembalian investasi. Berdasarkan penerapan ipteks ini diharapkan bagi pelaku UMKM agar dapat menggunakan metode nilai waktu sekarang sebagai pertimbangan dalam pengambilan keputusan investasi.

\section{DAFTAR PUSTAKA}

Blocher, E. J., Stout, D. E., \& Cokins, G. (2010). Cost Management: A strategic emphasis, $5^{\text {th }}$ Edition. United States: McGraw-Hill/Irwin.

Block, S. B., Hirt, G. A., \& Danielsen, B. R. (2017). Foundations of financial management, $16^{\text {th }}$ Edition. United States: McGraw-Hill Education.

Bustam, N. H. (2016). Pengaruh jumlah unit, PDB dan investasi UMKM terhadap penyerapan tenaga kerja di Indonesia periode 2009-2013. Jurnal Kutubkhannah, 19(2), 250-261. suska.ac.id/index.php/Kutubkhanah/article/view/2555

http://ejournal.uin-

Frensiska, M., Jonathan, R., \& Lau, E. A. (2015). Pengembalian investasi pada PT. Paula Jaya di Samarinda. Ekonomia, 4(3), 1-5. http://ejurnal.untagsmd.ac.id/index.php/EKM/article/view/1608

Hansen, D. R., \& Mowen, M. M. (2007). Managerial accounting, $8^{\text {th }}$ Edition. United States: Thomson South-Western.

Hilton, R. W., \& Platt, D. E. (2017). Managerial accounting: Creating value in a dynamic business environment, $11^{\text {th }}$ Edition. United States: McGraw-Hill Education.

Horngren, C. T., Sundem, G. L., Elliott, J. A., \& Philbrick, D. R. (2014). Introduction to financial accounting, $11^{\text {th }}$ Edition. United States: Pearson Education, Inc.

Kieso, D. E., Weygandt, J. J., \& Warfield, T. D. (2013). Intermediate accounting, $15^{\text {th }}$ Edition. United States: John Wiley \& Sons, Inc.

Mahastanti, L. A. (2011). Faktor-faktor yang dipertimbangkan investor dalam melakukan investasi. Jurnal Manajemen Teori dan Terapan, 4(3), 37-51. https://ejournal.unair.ac.id/index.php/JMTT/article/view/2424

Mulyadi. (2001). Akuntansi manajemen: Konsep, manfaat, dan rekayasa, Edisi 3. Jakarta: Penerbit Salemba Empat.

Puspitaningtyas, Z. (2012). Relevansi nilai informasi akuntansi dan manfaatnya bagi investor. EKUITAS, 16(2), 164-183. https://ejournal.stiesia.ac.id/ekuitas/article/view/214

Ross, S. A., Westerfield, R. W., \& Jaffe, J. (2013). Corporate finance, $10^{\text {th }}$ Edition. United States: McGraw-Hill/Irwin

Suparwo, A., Suhendi, H., Rachman, R., Arifin, T., \& Shobary, M. N. (2018). Strategi 
pengembangan usaha pada UMKM Baju Bayi Indra Collection. Jurnal Abdimas BSI: Jurnal Pengabdian kepada Masyarakat, 1(2), 208-214. https://ejournal.bsi.ac.id/ejurnal/index.php/abdimas/article/view/3734

Warren, C. S., Reeve, J. M., \& Duchac, J. E. (2018). Financial accounting, $15^{\text {th }}$ Edition. United States: Cengage Learning.

Yuliani. (2013). Implikasi keputusan investasi terhadap nilai perusahaan Sektor Real Estate and Property di Bursa Efek Indonesia: Faktor risiko dan rasio likuiditas sebagai variabel intervening. Jurnal Manajemen dan Bisnis Sriwijaya, 11(3), 211-232. https://ejournal.unsri.ac.id/index.php/jmbs/article/view/3195 